Article

\title{
In Vitro Evaluation of Neutral Aryloximes as Reactivators for Electrophorus eel Acetylcholinesterase Inhibited by Paraoxon
}

\author{
Daniel A. S. Kitagawa ${ }^{1,2}$ (D) Samir F. de A. Cavalcante ${ }^{2,3,4,5, *(\mathbb{D}, \text { Reuel L. de Paula }}{ }^{2,6} \mathbb{D}^{\text {, }}$ \\ Rafael B. Rodrigues ${ }^{2}$, Leandro B. Bernardo ${ }^{2}$, Munique C. J. da Silva ${ }^{2}{ }^{\circledR}$, Thiago N. da Silva ${ }^{4}$, \\ Wellington V. dos Santos ${ }^{7,8}$, José M. Granjeiro ${ }^{6}$, Joyce S. F. D. de Almeida ${ }^{1} \mathbb{D}$, \\ Marcos C. Barcellos ${ }^{2}$, Ana Beatriz de A. Correa ${ }^{2}$ (D), Tanos C. C. França ${ }^{1,5}$ (D), Kamil Kuča ${ }^{5, *(D)}$ and \\ Alessandro B. C. Simas ${ }^{3, * \mathbb{D}}$ \\ 1 Laboratory of Molecular Modelling Applied to Chemical and Biological Defense (LMACBD), \\ Military Institute of Engineering (IME), Praça General Tibúrcio 80, Rio de Janeiro 22290-270, Brazil \\ 2 Brazilian Army Institute of Chemical, Biological, Radiological and Nuclear Defense (IDQBRN), \\ Brazilian Army Technological Center (CTEx), Avenida das Américas 28705, Rio de Janeiro 23020-470, Brazil \\ 3 Walter Mors Institute of Research on Natural Products (IPPN), Federal University of Rio de Janeiro (UFRJ), \\ CCS, Bloco H, Rio de Janeiro 21941-902, Brazil \\ 4 Castelo Branco University (UCB), School of Pharmacy, Avenida Santa Cruz 1631, \\ Rio de Janeiro 21710-255, Brazil \\ 5 Department of Chemistry, Faculty of Science, University of Hradec Králové, Rokitanskeho 62, \\ 50003 Hradec Králové, Czech Republic \\ 6 National Institute of Metrology, Standardization and Industrial Quality (INMETRO), Avenida Nossa \\ Senhora das Graças 50, Duque de Caxias 25250-020, Brazil \\ 7 Emergency and Rescue Department (DSE), Rio de Janeiro State Fire Department (CBMERJ), \\ Praça São Salvador 4, Rio de Janeiro 22231-170, Brazil \\ 8 School of Biomedicine, University Universus Veritas (UNIVERITAS), Rua Marquês de Abrantes 55, \\ Rio de Janeiro 22230-060, Brazil \\ * Correspondence: samir.cavalcante@eb.mil.br (S.F.d.A.C.); kamil.kuca@uhk.cz (K.K.); \\ abcsimas@nppn.ufrj.br (A.B.C.S.)
}

Received: 9 September 2019; Accepted: 4 October 2019; Published: 8 October 2019 updates

\begin{abstract}
Casualties caused by organophosphorus pesticides are a burden for health systems in developing and poor countries. Such compounds are potent acetylcholinesterase irreversible inhibitors, and share the toxic profile with nerve agents. Pyridinium oximes are the only clinically available antidotes against poisoning by these substances, but their poor penetration into the blood-brain barrier hampers the efficient enzyme reactivation at the central nervous system. In searching for structural factors that may be explored in future SAR studies, we evaluated neutral aryloximes as reactivators for paraoxon-inhibited Electrophorus eel acetylcholinesterase. Our findings may result into lead compounds, useful for development of more active compounds for emergencies and supportive care.
\end{abstract}

Keywords: acetylcholinesterase; pesticides; neutral oximes; antidotes; drug design

\section{Introduction}

Acetylcholinesterase (AChE, EC 3.1.1.7, 1) is a serine-esterase, a key enzyme for the parasympathetic neurotransmission. This enzyme can be found in the brain, erythrocytes, and muscles, being responsible for the hydrolysis of the neurotransmitter acetylcholine (ACh, 2) into 
its two precursors, acetate (3) and choline (4), ending the potential action at the post-synaptic cleft (Scheme 1) [1-4]

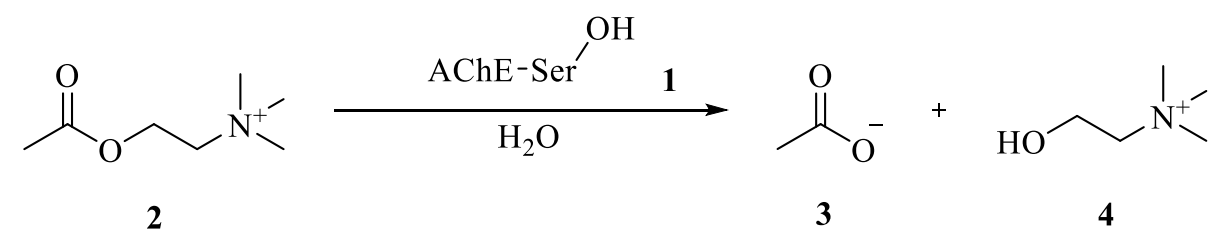

Scheme 1. Hydrolysis of ACh by AChE.

The hydrolysis of ACh by AChE is accomplished at the esteratic site (a catalytic triad composed by residues serine, histidine, and glutamate), which is highly conserved throughout the species. Inhibition of the catalytic serine residue via phosphorylation leads to accumulation of ACh, causing overstimulation of cholinergic innervations and ultimately, death [5-8]. Organophosphorus (OP) compounds are well-studied AChE inhibitors. The nerve agents sarin (5), soman (6), tabun (7), VX (8), and pesticides such as paraoxon (9) and malathion (10), are relevant examples of such compounds (Figure 1) [8,9]. While nerve agents are strictly regulated by the Chemical Weapons Convention (CWC) [10], a multilateral treaty that entered into force in 1997, pesticides are not regulated by any international agency, and their use is still subjected to each country's discretion. Consequently, non-developed and even developing countries still use pesticides already forbidden in the United States and Europe [11-14]. Recently, the Brazilian Parliament has discussed a controversial lift of the ban for using some aggressive pesticides, raising fears of pollution of lands, water courses, and groundwater, as well as the intoxication of workers and animals [15-18]. Besides economic impact in trade agreements, environmental and occupational issues, accidental poisoning of children, and suicide attempts are also additional costs for the governmental health systems [8,19-27]. These harmful chemicals are also associated with neurodegenerative diseases [28].

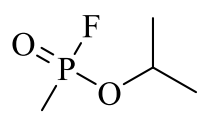

5

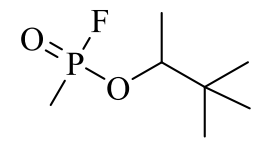

6

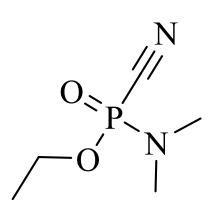

7<smiles>CCOP(C)(=O)SCCN(C(C)C)C(C)C</smiles>

8<smiles>CCOP(=O)(OCC)Oc1ccc([N+](=O)[O-])cc1</smiles>

9<smiles>CCOC(=O)CC(SP(=S)(OCC)OCC)C(=O)OCC</smiles>

Figure 1. Toxic organophosphorus compounds.

Aiming to control mosquito vectors in densely populated areas of the tropical countries, insecticides have been aerosolized. Despite of the inefficiency of this methodology and studies accounting for development of vector's resistance, it is still used. Tropical diseases are a burden for health systems in developing and under-developed countries. For example, arboviruses in Brazil transmitted by Aedes aegypti (Dengue, Yellow Fever, Zika, and Chikungunya) and Anopheles sp. (Malaria) have high rate of mortality and morbidity, among other mosquito-borne diseases. Brazilian National Health 
System (Sistema Único de Saúde-SUS) and other ministries have spent large sums to try to control these vectors and treat affected people. In Brazilian cities, an aerosol dispositive (in Brazilian Portuguese, this aerosol is known popularly as "fumacê") which contains malathion (10) has been used. However, it is a non-selective pesticide, leading to not only resistance, but also accidental and occupational poisonings, which may cause additional costs to SUS. Besides, it is also related to elimination of pollinator species. Malathion is in vivo converted to a more toxic metabolite, malaoxon (11). Parathion (12) reacts similarly with oxidases to yield the more toxic compound, paraoxon (9, Scheme 2) [29-34].

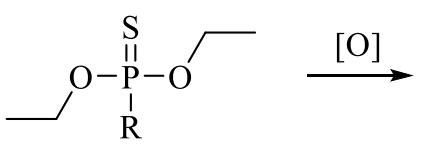

10,12<smiles>[R]=[O+]c1ccc(OC)cc1</smiles>

9, 12<smiles>[R]P(=O)(OCC)OCC</smiles>

9, 11<smiles>[R]OC(=O)C(CC(=O)OCC)SCC</smiles>

10,11

Scheme 2. Conversion of thions to oxons by oxidases.

Pesticides oxo-forms [Oxons $(\mathbf{9}, \mathbf{1 1})]$ are more toxic than their thio forms [thions $(\mathbf{1 0}, \mathbf{1 2})]$, although both are able to phosphorylate the catalytic serine residue in AChE (1), bringing about ACh (2) accumulation. Thio forms are converted slowly in the organism to more toxic oxo forms. This process is called "lethal synthesis" [35]. Depending on the level of exposure, poisoning may be fatal due to the SLUDGEM syndrome (salivation, lacrimation, urination, defecation, gastrointestinal disturbs, emesis, miosis, and muscle spasms). Scheme 3 shows a representation of reaction between an oxon $(\mathbf{9}, \mathbf{1 1})$ and AChE (1), yielding an oxon-AChE adduct [36].

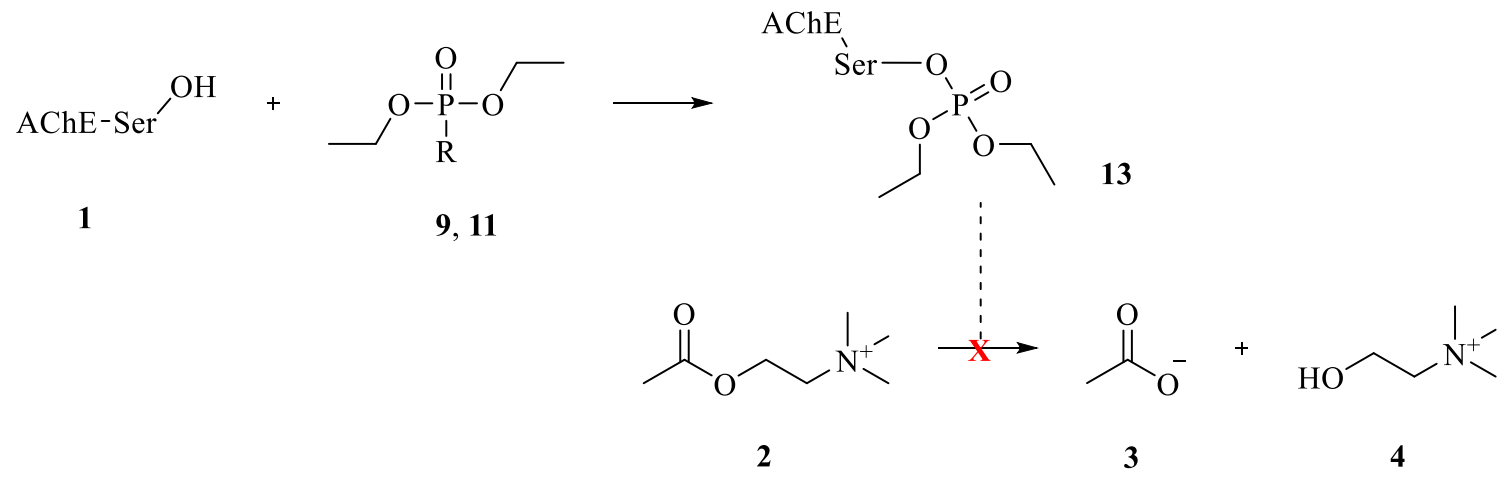

Scheme 3. AChE inhibition by oxons.

Intoxication caused by oxons must be rapidly addressed. Treatment usually employs a combination of up to three different drugs: an enzymatic reactivator, to displace the organophosphorus moiety from the serine residue (currently pyridinium oximes), an anticholinergic agent, to reduce the cholinergic stimulus, and an anticonvulsant, to control seizures. Delays in medical response may lead to $\mathrm{AChE}$ reactivators being ineffective, as excitatory neuronal mechanisms take over. This event has brought about the use of GABA agonists and glutamate antagonists in organophosphorus poisoning. Depending on the agent, enzymatic aging may occur, rendering no possibility of AChE reactivation 
with therapeutically available compounds, due to the formation of a stable phosphate ion between phosphorylated serine and protonated histidine at esteratic site [37-41].

As we mentioned above, to this date, pyridinium oximes are the only clinically available $\mathrm{AChE}$ reactivators for organophosphate poisoning. Pralidoxime (2-PAM, 14, $\mathrm{X}^{-}$is either chloride, iodide, or mesylate), obidoxime (15, $\mathrm{X}^{-}$is chloride), trimedoxime (TMB, $\mathbf{1 6}, \mathrm{X}^{-}$is bromide), $\mathrm{HI}-6$ (17, $\mathrm{X}^{-}$is chloride), HLö-7 (18, $\mathrm{X}^{-}$is chloride), and $\mathrm{K} 027\left(\mathbf{1 9}, \mathrm{X}^{-}\right.$is bromide) are examples of active compounds $[18,41,42]$. At physiological $\mathrm{pH}$, they are converted to oximates, nucleophilic species that displace the OP moiety, reactivating the enzyme. Atropine (20) and diazepam (21) are the other components of antidote kit, as anticholinergic and anticonvulsant drugs, respectively (Figure 2).<smiles></smiles>

14<smiles></smiles>

17<smiles>[Y20]COC[n+]1ccc(/C=N/O)cc1</smiles>

15<smiles>[Y20]CCC[n+]1ccc(/C=N/O)cc1</smiles>

16<smiles>O=C(OC1CC2CCC(C2)C1)C(CO)c1ccccc1</smiles>

20<smiles>CN1C(=O)CN=C(c2ccccc2)c2cc(Cl)ccc21</smiles>

21

Figure 2. Structures of compounds used for organophosphate poisoning.

Scheme 4 represents the reaction of pralidoxime oximate (22) with an oxon-AChE adduct (13). Although they are the only current class available for clinical use, their permeability through the blood-brain barrier is limited, due to their positive charge, reducing their effectiveness at the central nervous system (CNS). Therefore, the development of molecules with improved physicochemical profile, able to reach higher concentrations in the brain for better and fast AChE reactivation, is warranted. Moreover, it is noteworthy that there is no universal antidote for the AChE irreversible inhibitors [43-46].

A number of research endeavors have aimed at the improvement of existing antidotes [47-54]. One of the limitations of current AChE reactivators is their ability to cross the blood-brain barrier (BBB), which reduces the amount of reactivator in the brain. The main goal of the present work was the evaluation of simple, neutral aryloximes as reactivators for paraoxon-inhibited AChE using Ellman's spectrophotometric assay and commercial Electrophorus eel as a source of $\mathrm{AChE}$, a model of study due to full homology of its active site in comparison to the human isoform, although some relevant differences have been noted [55-57]. Thus, we chose to assay simple non-cationic aryloximes, substituted with electron withdrawing or donating groups for new insights on structural requirements to prospective novel lead compounds with enhanced pharmacokinetics $[46,49,58]$. 
<smiles>C[n+]1cccc(/C=N/[O-])c1</smiles><smiles></smiles>

22<smiles>CCCCCCCC[Ga]OP(=O)(OCC)OCC</smiles>

13<smiles>CCOP(=O)(OCC)O/N=C/c1ccc[n+](C)c1</smiles>

1
23

Scheme 4. Reactivation of AChE by pyridinium oximates.

\section{Experimental}

\subsection{General Information}

Syntheses of all neutral aryloximes and reference compounds obidoxime dichloride and trimedoxime dibromide have been detailed in our previous paper, with yields varying from 40 to $98 \%$ of pure products [55]. Their purity was checked using TLC-MS, GC-MS, and LC-MS before assays. Acetylthiocholine iodide (ATCI), paraoxon-ethyl 90\%, 5,5'-dithiobis-(2-nitrobenzoic) acid (DTNB), lyophilized acetylcholinesterase from Electrophorus eel (EeAChE, 1000U per mg protein, type V-S, C2888), pralidoxime iodide (2-PAM), dimethyl sulfoxide (DMSO, biological grade, dry, oxygen-free sealed bottle), sodium hydroxide (pellets), sodium phosphate monobasic hydrate, and sodium phosphate dibasic dihydrate were purchased from Sigma-Aldrich (São Paulo, Brazil). Absolute ethanol was purchased from Tedia (Rio de Janeiro, Brazil). Purified water was obtained from Millipore Milli-Q system (18.2 $\mathrm{M} \Omega \mathrm{cm}$ at $25^{\circ} \mathrm{C}$, Millipore Brazil, São Paulo, Brazil). TLC (Thin Layer Chromatography) aluminum plates coated with silica gel $\mathrm{F}_{254}$ were purchased from Merck Brazil (São Paulo-SP, Brazil). Camag TLC-MS (Thin Layer Chromatography-Mass Spectrometry) interface was used to follow reactions (AuTeC, São Paulo, Brazil). GC-MS (Gas Chromatography-Mass Spectrometry) data were obtained from Agilent 6890 GC system equipped with 5975C mass spectrometer detector (Billerica, Massachusetts, USA). LC-MS (liquid chromatography-mass spectrometry) data were obtained from Agilent 1210 LC system equipped with 6410B triple quadrupole mass spectrometer detector (Billerica, Massachusetts, USA). SpectraMax Plus 384 microplate reader (Molecular Devices, San Jose, California, USA) was used in all assays. Kasvi 96-wells microplates were purchased from Kasvi Brasil (São José dos Pinhais, Paraná, Brazil). Gilson single channel pipettes were purchased from Gilson Inc. (Middleton, Wisconsin, USA) and Eppendorf 8-channel pipettes were acquired from Eppendorf Brasil (São Paulo-SP, Brazil). Ellman's tests [59] were performed in triplicate, at three different assays, by at least three different operators, measured at $24^{\circ} \mathrm{C} \pm 2{ }^{\circ} \mathrm{C}$. Microsoft Excel $2010^{\circledR}$ was used for all calculations. All disposable materials and glassware in contact with paraoxon were decontaminated with aqueous solution containing $10 \% \mathrm{w} / \mathrm{v} \mathrm{NaOH}$ and $10 \% \mathrm{w} / \mathrm{v} \mathrm{NaClO}(\mathrm{pH}=14)$ for $48 \mathrm{~h}$ at room temperature before correct disposal. Estimations of $\mathrm{pKa}$ and $\log \mathrm{P}$ for reference antidotes and test compounds were obtained from ChemAxon Online Suite (chemicalize.org).

\subsection{Preparation of Test Solutions}

Fresh solutions of paraoxon (final concentrations in wells from $10^{-3}$ to $10^{-9} \mathrm{~mol} / \mathrm{L}$ ) were prepared by dissolving the commercial standard in absolute ethanol and stored at $-20{ }^{\circ} \mathrm{C}$ until use. Stock 
solutions of test oximes and clinical references $\left(10^{-2} \mathrm{~mol} / \mathrm{L}\right)$ were prepared by dissolution in DMSO, and phosphate buffer solution (PBS, pH $7.60 \pm 0.10$ ) was added to prepare test solutions (final concentrations in wells 1000, 100 and $10 \mu \mathrm{mol} / \mathrm{L}$ ). They were sonicated for $5 \mathrm{~min}$ before use. During experiments, all solutions were kept at $0{ }^{\circ} \mathrm{C}$. DMSO did not affect measurements in our conditions [60].

\subsection{Ellman's Spectrophotometric Assays}

Ellman's assay was used for determination of optimal paraoxon concentration and reactivation level. It was performed in accordance to our previously published procedure [60], using 96-wells microplates (final volume $200 \mu \mathrm{L}$ ). For AChE inhibition, we adjusted the microplate reader to $412 \mathrm{~nm}$, a wavelength at which the acetylthiocholine-DTNB adduct absorbs, and pipetted $70 \mu \mathrm{L}$ of EeAChE $2.14 \mathrm{U} / \mathrm{mL}$ (prepared from commercial lyophilized), $80 \mu \mathrm{L}$ of DTNB $0.4 \mathrm{mg} / \mathrm{mL}, 20 \mu \mathrm{L}$ of PBS, $10 \mu \mathrm{L}$ of paraoxon solution (positive control, $\mathrm{A}_{\mathrm{i}}$; CAUTION as paraoxon is a potent cholinesterase inhibitor) or $10 \mu \mathrm{L}$ of PBS (negative control, $\mathrm{A}_{0}$ ), incubating for $10 \mathrm{~min}$ for inhibition reaction. Then, we added $20 \mu \mathrm{L}$ of ATCI $1 \mathrm{mmol} / \mathrm{L}$ and read the absorbance in different times $(0,15,30$, and $60 \mathrm{~min})$ to calculate enzyme inhibition $\left(A_{i}\right)$. AChE inhibition percent was calculated using Equation (1).

$$
\% I=100 \times \frac{A_{0}-A_{i}}{A_{0}}
$$

For AChE reactivation using oximes, we adjusted microplate reader to $412 \mathrm{~nm}$ and pipetted $70 \mu \mathrm{L}$ of EeAChE $2.14 \mathrm{U} / \mathrm{mL}, 80 \mu \mathrm{L}$ of DTNB $0.4 \mathrm{mg} / \mathrm{mL}, 10 \mu \mathrm{L}$ of inhibitor. After inhibition reaction (10 min), we added $20 \mu \mathrm{L}$ standard antidotes or test molecules in different concentrations and waited for $30 \mathrm{~min}$ for reactivation reaction. At last, we pipetted $20 \mu \mathrm{L}$ of ATCI $1 \mathrm{mmol} / \mathrm{L}$ and read the absorbance $\left(\mathrm{A}_{\mathrm{r}}\right)$ in different times $(0,15,30$, and $60 \mathrm{~min})$ to calculate enzyme reactivation. AChE reactivation percent was calculated using Equation (2).

$$
\% R=100 \times \frac{A_{r}-A_{i}}{A_{0}-A_{i}}
$$

\section{Results and Discussion}

To determine the highest concentration of paraoxon to be used in our Ellman's conditions without causing full inhibition of EeAChE, which may lead to inconsistent results, we set forth the inhibition assay with paraoxon final concentrations ranging from $10^{-3}$ to $10^{-9} \mathrm{~mol} / \mathrm{L}$ (in ethanol), setting $10 \mathrm{~min}$ as the inhibition time. We also intended to determine the detection limit for our method using paraoxon as EeAChE inhibitor.

After $10 \mathrm{~min}$ of incubation of the enzyme with organophosphate, we read the absorbance immediately after the addition of ATCI and at each $15 \mathrm{~min}$ (15 to $60 \mathrm{~min}$ ). The highest inhibition achieved was 92.5 and $93.3 \%$, at $10^{-4}$ and $10^{-5} \mathrm{~mol} / \mathrm{L}$, respectively, after $15 \mathrm{~min}$ of addition of substrate. These values were virtually the same during all measured times (30 and $60 \mathrm{~min}$ ). Based on the results, for all reactivation experiments we opted for $10^{-5} \mathrm{~mol} / \mathrm{L}$ as paraoxon concentration, to ensure safety to all operators during the experiments (inhibition data available in Table S1). Paraoxon concentrations of $10^{-7}$ to $10^{-9} \mathrm{~mol} / \mathrm{L}$ led to inconsistent results, confirming that $10^{-5} \mathrm{~mol} / \mathrm{L}$ is the limit of detection for our assay (final concentrations of EeAChE and ATCI, $10^{-4} \mathrm{~mol} / \mathrm{L}$ and $2.14 \mathrm{U} / \mathrm{mL}$, respectively), as previously reported [61].

Table 1 lists all 33 neutral aryloximes tested (23a-ag), their estimated properties, and reactivation percent at different concentrations. Synthesis of tested compounds from related aldehydes (24a-ag) using microwave irradiation has been described in our previous paper [55], in accordance with Scheme 5 . 
Table 1. Oximes 22a-ag synthesized for assay in this work.

\begin{tabular}{|c|c|c|c|c|c|c|c|}
\hline \multirow{2}{*}{ Entry } & \multirow{2}{*}{ Code } & \multirow{2}{*}{ Name } & \multirow{2}{*}{$\mathrm{pKa}^{1}$} & \multirow{2}{*}{$\log P$} & \multicolumn{3}{|c|}{ Reactivator Concentration $(\mu \mathrm{mol} / \mathrm{L})$} \\
\hline & & & & & 1000 & 100 & 10 \\
\hline 1 & $22 a$ & 2-hydroxybenzaldoxime & $\begin{array}{c}6.61 \\
(\mathrm{OH}=9.99)\end{array}$ & 1.39 & $9 \pm 1$ & $4 \pm 1$ & $1 \pm 0$ \\
\hline 2 & $22 \mathrm{~b}$ & 3-hydroxybenzaldoxime & $\begin{array}{c}7.09 \\
(\mathrm{OH}=9.74)\end{array}$ & 1.39 & $3 \pm 0$ & $3 \pm 0$ & $2 \pm 0$ \\
\hline 3 & $22 \mathrm{c}$ & 4-hydroxybenzaldoxime & $\begin{array}{c}7.57 \\
(\mathrm{OH}=10.15)\end{array}$ & 1.39 & $6 \pm 1$ & $6 \pm 1$ & $6 \pm 1$ \\
\hline 4 & $22 \mathrm{~d}$ & 2-methoxybenzaldoxime & 6.69 & 1.54 & $2 \pm 0$ & $2 \pm 0$ & $1 \pm 0$ \\
\hline 5 & $22 \mathrm{e}$ & 3-methoxybenzaldoxime & 7.20 & 1.54 & $4 \pm 0$ & $1 \pm 0$ & $1 \pm 0$ \\
\hline 6 & $22 \mathrm{f}$ & 4-methoxybenzaldoxime & 7.69 & 1.54 & $4 \pm 1$ & $2 \pm 0$ & $2 \pm 0$ \\
\hline 7 & $22 \mathrm{~g}$ & 2-bromobenzaldoxime & 6.96 & 2.46 & $3 \pm 0$ & $2 \pm 0$ & $2 \pm 0$ \\
\hline 8 & $22 \mathrm{~h}$ & 3-bromobenzaldoxime & 7.31 & 2.46 & $4 \pm 0$ & $1 \pm 0$ & 0 \\
\hline 9 & $22 \mathrm{i}$ & 4-bromobenzaldoxime & 6.69 & 2.46 & $2 \pm 0$ & $2 \pm 0$ & $2 \pm 0$ \\
\hline 10 & $22 \mathrm{j}$ & 2-chlorobenzaldoxime & 6.80 & 2.30 & $30 \pm 2$ & $7 \pm 1$ & $2 \pm 0$ \\
\hline 11 & $22 \mathrm{k}$ & 3-chlorobenzaldoxime & 7.26 & 2.30 & $3 \pm 0$ & $2 \pm 0$ & $1 \pm 0$ \\
\hline 12 & 221 & 4-chlorobenzaldoxime & 6.67 & 2.30 & $3 \pm 0$ & $3 \pm 0$ & $1 \pm 0$ \\
\hline 13 & $22 \mathrm{~m}$ & 2-fluorobenzaldoxime & 6.82 & 1.84 & $4 \pm 0$ & $1 \pm 0$ & $3 \pm 0$ \\
\hline 14 & $22 n$ & 3-fluorobenzaldoxime & 7.11 & 1.84 & $4 \pm 0$ & $2 \pm 0$ & $2 \pm 1$ \\
\hline 15 & 220 & 4-fluorobenzaldoxime & 6.80 & 1.84 & $3 \pm 0$ & $2 \pm 0$ & $2 \pm 0$ \\
\hline 16 & $22 p$ & $\begin{array}{l}\text { 2-trifluoromethyl } \\
\text { benzaldoxime }\end{array}$ & 5.52 & 2.57 & $26 \pm 3$ & $5 \pm 0$ & $1 \pm 0$ \\
\hline 17 & $22 q$ & $\begin{array}{l}\text { 3-trifluoromethyl } \\
\text { benzaldoxime }\end{array}$ & 6.13 & 2.57 & $77 \pm 4$ & $5 \pm 0$ & $1 \pm 0$ \\
\hline 18 & $22 \mathrm{r}$ & $\begin{array}{l}\text { 4-trifluoromethyl } \\
\text { benzaldoxime }\end{array}$ & 6.29 & 2.57 & $10 \pm 1$ & $4 \pm 0$ & $1 \pm 0$ \\
\hline 19 & $22 \mathrm{~s}$ & 2-methylbenzaldoxime & 8.08 & 2.21 & $6 \pm 0$ & $1 \pm 0$ & $1 \pm 0$ \\
\hline 20 & $22 \mathrm{t}$ & 3-methylbenzaldoxime & 7.97 & 2.21 & $12 \pm 2$ & $1 \pm 0$ & 0 \\
\hline 21 & $22 \mathrm{u}$ & 4-methylbenzaldoxime & 8.14 & 2.21 & $14 \pm 2$ & 0 & 0 \\
\hline 22 & $22 \mathrm{v}$ & 4-isopropylbenzaldoxime & 8.21 & 2.94 & $2 \pm 0$ & $1 \pm 0$ & $2 \pm 0$ \\
\hline 23 & $22 \mathrm{w}$ & 3-nitrobenzaldoxime & 5.83 & 1.64 & $6 \pm 0$ & $3 \pm 0$ & $5 \pm 1$ \\
\hline 24 & $22 x$ & 4-nitrobenzaldoxime & 5.80 & 1.64 & $8 \pm 1$ & $7 \pm 1$ & $4 \pm 1$ \\
\hline 25 & $22 y$ & $\begin{array}{c}\text { 4-(N,N-dimethylamino) } \\
\text { benzaldoxime }\end{array}$ & 8.71 & 1.80 & $7 \pm 1$ & $6 \pm 0$ & $2 \pm 0$ \\
\hline 26 & $22 z$ & $\begin{array}{l}\text { 4-(N,N-diethylamino) } \\
\text { benzaldoxime }\end{array}$ & 8.80 & 2.52 & $7 \pm 1$ & $5 \pm 1$ & $5 \pm 1$ \\
\hline 27 & $22 \mathrm{aa}$ & Vanillin oxime & $\begin{array}{c}7.18 \\
(\mathrm{OH}=10.60)\end{array}$ & 1.23 & $5 \pm 0$ & $4 \pm 0$ & $4 \pm 1$ \\
\hline 28 & $22 \mathrm{ab}$ & Isovanillin oxime & $\begin{array}{c}6.21 \\
(\mathrm{OH}=10.47)\end{array}$ & 1.23 & $10 \pm 0$ & $4 \pm 0$ & $4 \pm 0$ \\
\hline 29 & $22 \mathrm{ac}$ & Orthovanillin oxime & $\begin{array}{c}7.18 \\
(\mathrm{OH}=10.14)\end{array}$ & 1.23 & $22 \pm 2$ & $4 \pm 0$ & $4 \pm 0$ \\
\hline 30 & 22ad & Pyridine-4-aldoxime & 10.21 & 0.48 & $6 \pm 1$ & $5 \pm 0$ & $1 \pm 0$ \\
\hline 31 & $22 \mathrm{ae}$ & Pyridine-2-aldoxime & 9.02 & 1.15 & $9 \pm 1$ & $3 \pm 0$ & 0 \\
\hline 32 & 22af & Isatin 3-oxime & $\begin{array}{c}7.13 \\
(\mathrm{NH}=15.51)\end{array}$ & 0.96 & $67 \pm 10$ & $15 \pm 2$ & $8 \pm 0$ \\
\hline 33 & 22ag & N-benzylisatin 3-oxime & 7.31 & 2.55 & $85 \pm 10$ & $9 \pm 1$ & $1 \pm 0$ \\
\hline 34 & 14 & Pralidoxime (2-PAM) ${ }^{2}$ & 7.63 & -3.26 & $39 \pm 2$ & $42 \pm 2$ & $16 \pm 3$ \\
\hline 35 & 15 & Obidoxime (OBD) & $7.51,8.11$ & -6.93 & $62 \pm 3$ & $88 \pm 3$ & $58 \pm 3$ \\
\hline 36 & 16 & Trimedoxime (TMB) & $8.63,9.24$ & -7.04 & $84 \pm 5$ & $75 \pm 3$ & $29 \pm 2$ \\
\hline
\end{tabular}

${ }^{1} \mathrm{pK}$ values refer to the dissociation $\mathrm{Ar}-\mathrm{C}=\mathrm{N}-\mathrm{OH} \rightleftharpoons \mathrm{Ar}-\mathrm{C}=\mathrm{N}-\mathrm{O}^{-}+\mathrm{H}^{+}$unless otherwise indicated ${ }^{2}$ Commercial source.<smiles>[R]c1ccc(C=O)cc1</smiles>

Scheme 5. Synthesis of aryloximes.

Table 1 shows that all compounds have higher calculated $\log \mathrm{P}$ values when compared to than the standard antidotes used (entries 34-36). Higher $\log \mathrm{P}$ values for the neutral oximes are expected to improve the ability of these simple molecules to cross the blood-brain barrier when compared with 
clinically available compounds. Presence of reactivator in CNS is necessary to exert central action [62,63]. Analysis of calculated $\mathrm{pKa}$ of tested compounds and comparison to clinical compounds showed similar pattern. SAR studies indicate that ideal pKa values are between 7.0 and 9.0, suggesting that some compounds may be relevant for further synthetic improvement. Neutral aryloximes synthesized were evaluated as reactivators for paraoxon-inhibited EeAChE in three different concentrations. Although some neutral oximes had been previously tested using blood samples (entries 6, 19, 26, and 31) [58], we decided to include them for comparison using our procedure.

2-PAM (14, entry 34) was selected for direct comparison due to structural similarity; obidoxime (15, entry 35) and trimedoxime (16, entry 36), bispyridinium compounds are more effective in AChE reactivation, and were also evaluated for further analysis. All compounds were screened at $412 \mathrm{~nm}$ to verify possible absorbance and oximolysis, i.e., reaction with Ellman's reagents. These values were deducted to retrieve confident values. Absorbance values were obtained after $30 \mathrm{~min}$ of incubation of test compounds with paraoxon-inhibited EeAChE. We also set as threshold $10 \pm 1 \%$ of reactivation of paraoxon-inhibited EeAChE to select compounds for further structural modification. We defined this value as the minimum score in accordance with the literature [64].

Literature reports that the maximum concentration tolerated in vivo for clinical compounds, pyridinium oximes, is $100 \mu \mathrm{mol} / \mathrm{L}[64,65]$. Neutral aryloximes lack of key structural motifs, for instance, cationic nitrogen for interaction with the catalytic anionic site of AChE. To evaluate the effect of concentration on EeAChE reactivation, we tested all neutral aryloximes at 1000, 100, and $10 \mu \mathrm{mol} / \mathrm{L}$. Reactivation at the highest concentration was achieved for some compounds, but they had no reactivation at $10 \mu \mathrm{mol} / \mathrm{L}$, whatsoever.

3-Oximes from isatin (entry 32) and N-benzylisatin (entry 33) were the only tested compounds to achieve the threshold at $100 \mu \mathrm{mol} / \mathrm{L}$, with isatin-3-oxime reactivating AChE more effectively than N-benzyl derivative. We speculate this outcome might be due to the steric hindrance of benzyl group, making more difficult the approach of the oximate to the phosphorus atom. Nonetheless, at $1000 \mu \mathrm{mol} / \mathrm{L}, \mathrm{N}$-benzyl isatin 3-oxime was slightly more active than non-benzylated analogue. Further studies, including in silico approaches, should be done in order to rationalize these results. Isatin derivatives have also previously been described as cholinesterase inhibitors, indicating that this motif may be a starting point for synthesis of more active compounds [66-72].

At $1000 \mu \mathrm{mol} / \mathrm{L}$, we could identify nine additional compounds. Salicylaldoxime (2hydroxybenzaldoxime, entry 1) presented some reactivation ability, as we hypothesize a positive effect by the neighboring hydroxyl group, contributing either to oximate generation or to its nucleophilicity [47]. Satisfyingly, this is an accessible compound which may be synthetically manipulated for optimization. 2-Chlorobenzaldoxime (entry 10) also presented good activity. Recent literature showed that this structural motif has been able to reactivate AChE inhibited by nerve agents [73,74]. All three trifluoromethyl-substituted benzaldoximes (entries 16-18) showed relevant reactivation of paraoxon-inhibited EeAChE. Interestingly, the 3-trifluoromethyl compound performed much better than 2- and 4- isomers, not in parallel with the calculated pKa, lower in 2-substituted isomer (Table 1, entries 16-18). We postulated that for 3-substituted compound, the polar hydrophobicity exerted by the C-F bonds, largely explored in medicinal chemistry, might play a role [75,76]. 3-methyl and 4-methylbenzaldoximes (entries 20 and 21, respectively) also showed good performance in reactivation of paraoxon-inhibited EeAChE. Conversely, the lower activities of 2-methyl isomer (entry 19) and 4-isopropylbenzaldoxime (entry 22) might be explained, respectively, by steric effects that affect the oximate attack proper interaction inside the active site. Isovanillin (entry 28) and, markedly, orthovanillin (entry 29) also performed satisfactorily. Neutral pyridine-4-aldoxime (entry 30) and pyridine-2-aldoxime (entry 31) exhibited significantly lower reactivation potency compared to 2-PAM, although they have structural similarity. This indicates the importance of quaternary nitrogen atom for development of active compounds [44]. 


\section{Conclusions}

In conclusion, after we surveyed across a series of simple, neutral oximes, in order to identify structures for further synthetic improvement, we could identify 12 substances whose motifs can be incorporated in development of lead compounds by analysis of different substitution patterns in order to address poisoning with paraoxon. We observed that either electron-donating or electron-withdrawing groups could not only bestow enhanced pharmacokinetics $(\mathrm{pKa}, \log \mathrm{P})$, but also reactivation potency. We are now testing the same compounds with other AChE isoforms for screening of compounds that may be useful for further development of novel antidotes for other pesticides and nerve agents' surrogates, and also AChE inhibitors.

Supplementary Materials: The following are available online at http://www.mdpi.com/2218-273X/9/10/583/s1. Table S1: Full results on inhibition of the EeAChE with paraoxon

Author Contributions: S.F.d.A.C., M.C.B., T.C.C.F., K.K., and A.B.C.S. conceived the project; D.A.S.K., T.N.d.S., W.V.d.S., L.B.B., and S.F.d.A.C. synthesized all tested compounds; R.L.d.P., J.M.G., and S.F.d.A.C. defined paraoxon concentration for assays; J.S.F.D.d.A. calculated all constants; D.A.S.K., R.B.R., M.C.J.d.S., T.N.d.S., W.V.d.S., A.B.d.A.C., and S.F.d.A.C performed reactivation assays; S.F.d.A.C., R.L.d.P., M.C.B., and A.B.d.A.C. prepared the original draft; S.F.d.A.C., T.C.C.F., K.K., and A.B.C.S. wrote and reviewed the presented form of the manuscript.

Funding: This research was funded by Organisation for the Prohibition of Chemical Weapons-OPCW, grant number L/ICA/ICB/201062/15 and Brazilian Army. Also supported by University of Hradec Kralove (Faculty of Science, VT2019-2021.

Acknowledgments: Authors would like to thank Maria do Carmo Pinto (IPPN) for donation of aldehydes, Central Analítica IPPN and Núcleo de Competência para o Desenvolvimento de Tecnologias de Carbono- NCDTC/CTEx for NMR spectra.

Conflicts of Interest: The authors declare no conflict of interest. The funders had no role in the design of the study; in the collection, analyses, or interpretation of data; in the writing of the manuscript, or in the decision to publish the results.

\section{References}

1. Taylor, P. The cholinesterases. J. Biol. Chem. 1991, 266, 4025-4028. Available online: http://www.jbc.org/ content/266/7/4025.long (accessed on 23 August 2019). [PubMed]

2. Taylor, P.; Radic, Z. The Cholinesterases: From Genes to Proteins. Annu. Rev. Pharmacol. Toxicol. 1994, 34, 281-320. [CrossRef] [PubMed]

3. Soreq, H.; Seidman, S. Acetylcholinesterase-New roles for an old actor. Nat. Rev. Neurosci. 2001, 2, $294-302$. [CrossRef] [PubMed]

4. Quinn, D.M. Acetylcholinesterase: Enzyme structure, reaction dynamics, and virtual transition states. Chem. Rev. 1987, 87, 955-979. [CrossRef]

5. Chatonnet, A.; Lockridge, O. Comparison of butyrylcholinesterase and acetylcholinesterase. Biochem. J. 1989, 260, 625-634. [CrossRef]

6. Sussman, J.L.; Silman, I. Acetylcholinesterase: Structure and use as a model for specific cation-protein interactions. Curr. Opin. Struct. Boil. 1992, 2, 721-729. [CrossRef]

7. Dvir, H.; Silman, I.; Harel, M.; Rosenberry, T.L.; Sussman, J.L. Acetylcholinesterase: From 3D Structure to Function. Chem. Interactions 2010, 187, 10-22. [CrossRef] [PubMed]

8. Eddleston, M.; Buckley, N.A.; Eyer, P.; Dawson, A.H. Management of acute organophosphorus pesticide poisoning. Lancet 2008, 371, 597-607. [CrossRef]

9. Costanzi, S.; Machado, J.-H.; Mitchell, M. Nerve Agents: What They Are, How They Work, How to Counter Them. ACS Chem. Neurosci. 2018, 9, 873-885. [CrossRef]

10. Organisation for the Prohibition of Chemical Weapons-OPCW. Convention on the Prohibition of the Development, Production, Stockpiling and Use of Chemical Weapons and on Their Destruction-CWC. 1997. Available online: www.opcw.org (accessed on 6 October 2019).

11. Bernardes, M.F.F.; Pazin, M.; Pereira, L.C.; Dorta, D.J. Impact of Pesticides on Environmental and Human Health. Available online: https://www.intechopen.com/books/toxicology-studies-cells-drugsand-environment/impact-of-pesticides-on-environmental-and-human-health (accessed on 23 August 2019). 
12. Pimentel, D. 'Environmental and Economic Costs of the Application of Pesticides Primarily in the United States'. Environ. Dev. Sustain. 2005, 7, 229-252. [CrossRef]

13. Ecobichon, D.J. Pesticide use in developing countries. Toxicology 2001, 160, 27-33. [CrossRef]

14. Atreya, K.; Sitaula, B.K.; Johnsen, F.H.; Bajracharya, R.S. Continuing Issues in the Limitations of Pesticide Use in Developing Countries. J. Agric. Environ. Ethics 2011, 24, 49-62. [CrossRef]

15. The Guardian. "Hundreds of new pesticides approved in Brazil under Bolsonaro". Available online: https://www.theguardian.com/environment/2019/jun/12/hundreds-new-pesticides-approved-brazilunder-bolsonaro (accessed on 23 August 2019).

16. Reuters. "Brazil approves rules for pesticides easing toxicity criteria". Available online: https://www.reuters.com/article/us-brazil-pesticides/brazil-approves-rules-for-pesticides-easingtoxicity-criteria-idUSKCN1UI2JJ (accessed on 23 August 2019).

17. Pignati, W.A.; Lima, F.A.N.S.; Lara, S.S.; Correa, M.L.M.; Barbosa, J.R.; Leão, L.H.C.; Pignatti, M.G. Spatial distribution of pesticide use in Brazil: A strategy for Health Surveillance. Ciência Saúde Coletiva 2017, 22, 3281-3293. [CrossRef]

18. Dasgupta, S.; Mamingi, N.; Meisner, C. Pesticide use in Brazil in the era of agroindustrialization and globalization. Environ. Dev. Econ. 2001, 6, 459-482. [CrossRef]

19. Nicolopoulou-Stamati, P.; Maipas, S.; Kotampasi, C.; Stamatis, P.; Hens, L. Chemical Pesticides and Human Health: The Urgent Need for a New Concept in Agriculture. Front. Public Heal. 2016, 4, 231. [CrossRef] [PubMed]

20. Eddleston, M.; Karalliedde, L.; Buckley, N.; Fernando, R.; Hutchinson, G.; Isbister, G.; Konradsen, F.; Murray, D.; Piola, J.C.; Senanayake, N.; et al. Pesticide poisoning in the developing world-A minimum pesticides list. Lancet 2002, 360, 1163-1167. [CrossRef]

21. Piccoli, C.; Cremonese, C.; Koifman, R.; Koifman, S.; Freire, C. Occupational exposure to pesticides and hematological alterations: A survey of farm residents in the South of Brazil. Ciência Saúde Coletiva 2019, 24, 2325-2340. [CrossRef]

22. Bardin, P.G.; van Eeden, S.F.; Moolman, J.A.; Foden, A.P.; Joubert, J.R. Organophosphate and Carbamate Poisoning. Arch. Intern. Med. 1994, 154, 1433-1441. [CrossRef]

23. Steenland, K. Chronic neurological effects of organophosphate pesticides. BMJ 1996, 312, $1312-1313$. [CrossRef]

24. Eskenazi, B.; Bradman, A.; Castorina, R. Exposures of children to organophosphate pesticides and their potential adverse health effects. Environ. Heal. Perspect. 1999, 107, 409-419. [CrossRef]

25. Kofman, O.; Berger, A.; Massarwa, A.; Friedman, A.; Abu Jaffar, A. Motor Inhibition and Learning Impairments in School-Aged Children Following Exposure to Organophosphate Pesticides in Infancy. Pediatr. Res. 2006, 60, 88-92. [CrossRef] [PubMed]

26. Pasiani, J.O.; Torres, P.; Silva, J.R.; Diniz, B.Z.; Caldas, E.D. Knowledge, Attitudes, Practices and Biomonitoring of Farmers and Residents Exposed to Pesticides in Brazil. Int. J. Environ. Res. Public Health 2012, 9, 3051-3068. [CrossRef]

27. Rastogi, S.K.; Tripathi, S.; Ravishanker, D. A study of neurologic symptoms on exposure to organophosphate pesticides in the children of agricultural workers. Indian J. Occup. Environ. Med. 2010, 14, 54-57. [CrossRef] [PubMed]

28. Mercey, G.; Verdelet, T.; Renou, J.; Kliachyna, M.; Baati, R.; Nachon, F.; Jean, L.; Renard, P.-Y. Reactivators of Acetylcholinesterase Inhibited by Organophosphorus Nerve Agents. Accounts Chem. Res. 2012, 45, 756-766. [CrossRef] [PubMed]

29. Litchfield, M.H. Estimates of acute pesticide poisoning in agricultural workers in less developed countries. Toxicol. Rev. 2005, 24, 271-278. [CrossRef] [PubMed]

30. Benelli, G.; Jeffries, C.L.; Walker, T. Biological Control of Mosquito Vectors: Past, Present, and Future. Insects 2016, 7, 52. [CrossRef] [PubMed]

31. Morais, S.A.; Urbinatti, P.R.; Sallum, M.A.M.; Kuniy, A.A.; Moresco, G.G.; Fernandes, A.; Nagaki, S.S.; Natal, D. Brazilian mosquito (Diptera: Culicidae) fauna: I. Anopheles species from Porto Velho, Rondônia state, western Amazon, Brazil. Revista do Instituto de Medicina Tropical de São Paulo 2012, 54, 331-335. [CrossRef] [PubMed]

32. Thatcher, B.D.; Tadei, W.P. Malaria vectors in the Brazilian Amazon: Anopheles of the subgenus Nyssorhynchus. Revista do Instituto de Medicina Tropical de São Paulo 2000, 42, 87-94. 
33. Corbel, V.; Achee, N.L.; Chandre, F.; Coulibaly, M.B.; Dusfour, I.; Fonseca, D.M.; Grieco, J.; Juntarajumnong, W.; Lenhart, A.; Martins, A.J.; et al. Tracking Insecticide Resistance in Mosquito Vectors of Arboviruses: The Worldwide Insecticide resistance Network (WIN). PLOS Neglected Trop. Dis. 2016, 10, e0005054. [CrossRef]

34. Achee, N.L.; Grieco, J.P.; Vatandoost, H.; Seixas, G.; Pinto, J.; Ching-Ng, L.; Martins, A.J.; Juntarajumnong, W.; Corbel, V.; Gouagna, C.; et al. Alternative strategies for mosquito-borne arbovirus control. PLOS Neglected Trop. Dis. 2019, 13, e0006822.

35. Peters, R.A. Croonian Lecture-Lethal synthesis. Proc. R. Soc. London. Ser. B: Boil. Sci. 1952, 139, 143-170.

36. Yanagisawa, N. [The nerve agent sarin: History, clinical manifestations, and treatment]. Brain Nerve 2014, 66, 561-569. [PubMed]

37. Antonijević, B.; Stojiljkovic, M.P. Unequal Efficacy of Pyridinium Oximes in Acute Organophosphate Poisoning. Clin. Med. Res. 2007, 5, 71-82. [CrossRef] [PubMed]

38. Aroniadou-Anderjaska, V.; Figueiredo, T.H.; Apland, J.P.; Prager, E.M.; Pidoplichko, V.I.; Miller, S.L.; Braga, M.F.M. Long-term neuropathological and behavioral impairments after exposure to nerve agents. Ann. N. Y. Acad. Sci. 2006, 1374, 17-28. [CrossRef] [PubMed]

39. Aroniadou-Anderjaska, V.; Figueiredo, T.H.; Apland, J.P.; Qashu, F.; Braga, M.F. Primary brain targets of nerve agents: The role of the amygdala in comparison to the hippocampus. NeuroToxicology 2009, 30, $772-776$. [CrossRef] [PubMed]

40. Moshiri, M.; Darchini-Maragheh, E.; Balali-Mood, M. Advances in toxicology and medical treatment of chemical warfare nerve agents. DARU J. Pharm. Sci. 2012, 20, 81. [CrossRef] [PubMed]

41. Čolović, M.B.; Krstić, D.Z.; Lazarević-Pašti, T.D.; Bondžić, A.M.; Vasić, V.M. Acetylcholinesterase inhibitors: Pharmacology and toxicology. Curr. Neuropharmacol. 2013, 11, 315-335. [CrossRef]

42. Wilson, I.B.; Ginsburg, S. Reactivation of alkylphosphate inhibited acetylcholinesterase by bis quaternary derivatives of 2-PAM and 4-PAM. Biochem. Pharmacol. 1959, 1, 200-206. [CrossRef]

43. Cannard, K.J. The acute treatment of nerve agent exposure. Neurol. Sci. 2006, 249, 86-94. [CrossRef]

44. Kuca, K.; Jun, D.; Musilek, K. Structural Requirements of Acetylcholinesterase Reactivators. Mini-Reviews Med. Chem. 2006, 6, 269-277. [CrossRef]

45. Worek, F.; Wille, T.; Koller, M.; Thiermann, H. Structural requirements for effective oximes - Evaluation of kinetic in vitro data with phosphylated human AChE and structurally different oximes. Chem. Interactions 2013, 203, 125-128. [CrossRef] [PubMed]

46. Milatovic, D.; Jokanović, M. Pyridinium Oximes as Cholinesterase Reactivators in the Treatment of OP Poisoning. In Handbook of Toxicology of Chemical Warfare Agents; Elsevier BV: San Diego, CA, USA, 2009; pp. 985-996.

47. Saint-André, G.; Kliachyna, M.; Kodepelly, S.; Louise-Leriche, L.; Gillon, E.; Renard, P.-Y.; Nachon, F.; Baati, R.; Wagner, A. Design, synthesis and evaluation of new $\alpha$-nucleophiles for the hydrolysis of organophosphorus nerve agents: Application to the reactivation of phosphorylated acetylcholinesterase. Tetrahedron 2011, 67, 6352-6361. [CrossRef]

48. Sit, R.K.; Radić, Z.; Gerardi, V.; Zhang, L.; Garcia, E.; Katalinić, M.; Amitai, G.; Kovarik, Z.; Fokin, V.V.; Sharpless, K.B.; et al. New Structural Scaffolds for Centrally Acting Oxime Reactivators of Phosphylated Cholinesterases*. J. Boil. Chem. 2011, 286, 19422-19430. [CrossRef] [PubMed]

49. Musilek, K.; Kuca, K.; Jun, D.; Dohnal, V.; Dolezal, M. Synthesis of the novel series of bispyridinium compounds bearing (E)-but-2-ene linker and evaluation of their reactivation activity against chlorpyrifos-inhibited acetylcholinesterase. Bioorganic Med. Chem. Lett. 2006, 16, 622-627. [CrossRef] [PubMed]

50. Timperley, C.M.; Banks, R.E.; Young, I.M.; Haszeldine, R.N. Synthesis of some fluorine-containing pyridinealdoximes of potential use for the treatment of organophosphorus nerve-agent poisoning. J. Fluor. Chem. 2011, 132, 541-547. [CrossRef]

51. Jokanovic, M. Structure-Activity Relationship and Efficacy of Pyridinium Oximes in the Treatment of Poisoning with Organophosphorus Compounds: A Review of Recent Data. Curr. Top. Med. Chem. 2012, 12, 1775-1789. [CrossRef]

52. Acharya, J.; Gupta, A.K.; Mazumder, A.; Dubey, D.K. In-vitro regeneration of sarin inhibited electric eel acetylcholinesterase by bis-pyridinium oximes bearing xylene linker. Eur. J. Med. Chem. 2009, 44, 1326-1330. [CrossRef] [PubMed] 
53. Acharya, J.; Dubey, D.K.; Srivastava, A.K.; Raza, S.K. In vitro reactivation of sarin-inhibited human acetylcholinesterase (AChE) by bis-pyridinium oximes connected by xylene linkers. Toxicol. Vitr. 2011, 25, 251-256. [CrossRef]

54. Musilek, K.; Jun, D.; Cabal, J.; Kassa, J.; Gunn-Moore, F.; Kuca, K. Design of a Potent Reactivator of Tabun-Inhibited AcetylcholinesteraseSynthesis and Evaluation of (E)-1-(4-Carbamoylpyridinium)-4-(4-hydroxyiminomethylpyridinium)-but-2-ene Dibromide (K203). J. Med. Chem. 2007, 50, 5514-5518. [CrossRef]

55. Cavalcante, S.F.A.; Kitagawa, D.A.S.; Rodrigues, R.B.; Bernardo, L.B.; da Silva, T.N.; dos Santos, W.V.; Correa, A.B.A.; de Almeida, J.S.F.D.; França, T.C.C.; Kuča, K.; et al. Synthesis and in vitro evaluation of neutral aryloximes as reactivators of Electrophorus eel Acetylcholinesterase inhibited by NEMP, a VX surrogate. Chem. Biol. Interact. 2019, 309. in press. [CrossRef]

56. Sahu, A.K.; Sharma, R.; Gupta, B.; Musilek, K.; Kuca, K.; Acharya, J.; Ghosh, K.K. Oxime-mediated in vitro reactivation kinetic analysis of organophosphates-inhibited human and electric eel acetylcholinesterase. Toxicol. Mech. Methods 2016, 26, 1-8. [CrossRef] [PubMed]

57. Worek, F.; Reiter, G.; Eyer, P.; Szinicz, L. Reactivation kinetics of acetylcholinesterase from different species inhibited by highly toxic organophosphates. Arch. Toxicol. 2002, 76, 523-529. [CrossRef] [PubMed]

58. Ribeiro, T.S.; Prates, A.; Alves, S.R.; Oliveira-Silva, J.J.; Riehl, C.A.S.; Figueroa-Villar, J.D. The effect of neutral oximes on the reactivation of human acetylcholinesterase inhibited with paraoxon. J. Braz. Chem. Soc. 2012, 23, 1216-1225. [CrossRef]

59. Ellman, G.L.; Courtney, K.; Andres, V.; Featherstone, R.M. A new and rapid colorimetric determination of acetylcholinesterase activity. Biochem. Pharmacol. 1961, 7, 88-95. [CrossRef]

60. Cavalcante, S.; Kitagawa, D.; Rodrigues, R.; Cardozo, M.; Paula, R.; Correa, A.B.; Simas, A. Straightforward, economical procedures for microscale ellman's test for cholinesterase inhibition and reactivation. Química Nova 2018, 41, 1192-1195. [CrossRef]

61. Pohanka, M.; Hrabinová, M.; Kuca, K.; Simonato, J.-P. Assessment of Acetylcholinesterase Activity Using Indoxylacetate and Comparison with the Standard Ellman's Method. Int. J. Mol. Sci. 2011, 12, 2631-2640. [CrossRef]

62. Sit, R.K.; Fokin, V.V.; Amitai, G.; Sharpless, K.B.; Taylor, P.; Radić, Z. Imidazole aldoximes effective in assisting butyrylcholinesterase catalysis of organophosphate detoxification. J. Med. Chem. 2014, 57, 1378-1389. [CrossRef]

63. Radić, Z.; Sit, R.K.; Kovarik, Z.; Berend, S.; Garcia, E.; Zhang, L.; Amitai, G.; Green, C.; Radić, B.; Fokin, V.V.; et al. Refinement of Structural Leads for Centrally Acting Oxime Reactivators of Phosphylated Cholinesterases*. J. Boil. Chem. 2012, 287, 11798-11809. [CrossRef]

64. Bajgar, J. Organophosphates/Nerve Agent Poisoning: Mechanism of Action, Diagnosis, Prophylaxis, And Treatment. Adv. Clin. Chem. 2004, 38, 151-216.

65. Tattersall, J.E.H. Ion channel blockade by oximes and recovery of diaphragm muscle from soman poisoning in vitro. Br. J. Pharmacol. 1993, 108, 1006-1015. [CrossRef]

66. Ozgun, D.O.; Yamali, C.; Gul, H.I.; Taslimi, P.; Gulcin, I.; Yanik, P.D.; Supuran, C.T. Inhibitory effects of isatin Mannich bases on carbonic anhydrases, acetylcholinesterase, and butyrylcholinesterase. J. Enzym. Inhib. Med. Chem. 2016, 31, 1-4. [CrossRef] [PubMed]

67. Chandra, M.P.; Rao, J.V. Biological evaluation of schiff bases of new isatin derivatives for anti alzheimer's activity. Asian J. Pharm. Clin. Res. 2014, 7, 114-117. Available online: https://innovareacademics.in/journals/ index.php/ajpcr/article/view/966 (accessed on 23 August 2019).

68. Barcelos, R.P.; Lima Portella, R.; Lugokenski, T.H.; Rosa, E.J.F.; Amaral, G.P.; Garcia, L.F.M.; Bresolin, L.; Carratu, V.; Soares, F.A.A.; Vargas Barbosa, N.B. Isatin-3-N4-benzilthiosemicarbazone, a non-toxic thiosemicarbazone derivative, protects and reactivates rat and human cholinesterases inhibited by methamidophos in vitro and in silico. Toxicol. In Vitro 2012, 26, 1030-1039. [CrossRef] [PubMed]

69. Boar, B.R.; Cross, A.J. Isatin Derivatives, Processes for the Preparation Thereof and Pharmacautical Composition Comprising the Same. WO 9312085, 24 June 1993.

70. Bridges, T.M.; Marlo, J.E.; Niswender, C.M.; Jones, C.K.; Jadhav, S.B.; Gentry, P.R.; Plumley, H.C.; Weaver, C.D.; Conn, P.J.; Lindsley, C.W. Discovery of the first highly M5-preferring muscarinic acetylcholine receptor ligand, an M5 positive allosteric modulator derived from a series of 5-trifluoromethoxy N-benzyl isatins. J. Med. Chem. 2009, 52, 3445-3448. [CrossRef] [PubMed] 
71. De Paula, R.L.; De Almeida, J.S.F.D.; Cavalcante, S.F.A.; Gonçalves, A.S.; Simas, A.B.C.; Franca, T.C.C.; Valis, M.; Kuca, K.; Nepovimova, E.; Granjeiro, J.M. Molecular Modeling and In Vitro Studies of a Neutral Oxime as a Potential Reactivator for Acetylcholinesterase Inhibited by Paraoxon. Molecules 2018, 23, 2954. [CrossRef] [PubMed]

72. Cavalcante, S.; Simas, A.; Kitagawa, D.; Bernardo, L.; Rodrigues, R.; Correa, A.; Paula, R.; Freitas, L.; Diz de Almeida, J.; França, T.; et al. Derivados da Indolin-2-ona e Seus Intermediários, Produtos, Métodos de Obtenção e Usos. BR1020180750046, 3 December 2018.

73. Zorbaz, T.; Malinak, D.; Mariković, N.; Maček Hrvak, N.; Zandona, A.; Novotny, M.; Sharka, A.; Andrys, R.; Benkova, M.; Soukup, O.; et al. Pyridinium Oximes with Ortho-Positioned Chlorine Moiety Exhibit Improved Physicochemical Properties and Efficient Reactivation of Human Acetylcholinesterase Inhibited by Several Nerve Agents. J. Med. Chem. 2018, 61, 10753-10766. [CrossRef] [PubMed]

74. Zorbaz, T.; Malinak, D.; Kuča, K.; Musilek, K.; Kovarik, Z. Butyrylcholinesterase inhibited by nerve agents is efficiently reactivated with chlorinated pyridinium oximes. Chem. Biol. Interact. 2019, 307, 16-20. [CrossRef] [PubMed]

75. Bassetto, M.; Ferla, S.; Pertusati, F. Polyfluorinated groups in medicinal chemistry. Futur. Med. Chem. 2015, 7, 527-546. [CrossRef] [PubMed]

76. Biffinger, J.C.; Kim, H.W.; DiMagno, S.G. The Polar Hydrophobicity of Fluorinated Compounds. ChemBioChem 2004, 5, 622-627. [CrossRef]

(C) 2019 by the authors. Licensee MDPI, Basel, Switzerland. This article is an open access article distributed under the terms and conditions of the Creative Commons Attribution (CC BY) license (http://creativecommons.org/licenses/by/4.0/). 